\title{
Down-Turner syndrome: case report and review
}

\author{
G J C M Van Buggenhout, B C J Hamel, J C M Trommelen, H Mieloo, \\ D F C M Smeets
}

Department of Human Genetics, University Hospital Nijmegen, PO Box 9101, $6500 \mathrm{HB}$ Nijmegen, The Netherlands G J C M Van Buggenhout B C J Hamel H Mieloo

D F C M Smeets

Institution for Mentally Retarded Patients,

Huize Assisië, The Netherlands J C M Trommelen

Correspondence to Dr Smeets. Received 4 February 1994 publication 19 May 1994

\begin{abstract}
We present a male patient with DownTurner mosaicism $(45, X / 46, X,+21 / 47, X Y$, +21 ) and review 27 similar cases reported so far. Clinical features of Down's syndrome were present in all cases, whereas a combination of features of both UllrichTurner syndrome and Down's syndrome was reported in $61 \%$ of the patients. However, one has to bear in mind that several stigmata of Ullrich-Turner syndrome can also be present in patients with Down's syndrome and vice versa.

In most of the patients two different cell lines were encountered, although cases with one, three, and even four different cell lines have been reported. Of 28 patients, 21 showed female external genitalia, four were phenotypically male, and three showed ambiguous genitalia. Only six patients $(21 \%)$ carried a $Y$ chromosome, which is far less than expected.
\end{abstract}

( $\mathcal{F}$ Med Genet 1994;31:807-810)

Chromosomal aneuploidy is quite frequent and may involve autosomes, as in Down's syndrome, or sex chromosomes, as in UllrichTurner syndrome. In contrast, double aneuploidy involving both autosomal and sex chromosomes is very rare. Sex chromosomal aneuploidy in combination with trisomy 21 includes Down-Klinefelter, Down-XXX, Down-XYY, and Down-Turner syndrome. ${ }^{1-4}$ Of these, Down-Turner syndrome is one of the most rare with only 27 cases being reported so far. We present a new case of Down-Turner mosaicism $(45, \mathrm{X} / 46, \mathrm{X},+21 / 47$, $\mathrm{XY},+21$ ), which was found during routine screening of a 59 year old male to confirm the clinical diagnosis of Down's syndrome and to rule out an inherited translocation. Cytogenetic and clinical features of all known cases are reviewed.

\section{Case report}

A 59 year old male, institutionalised from the age of 8 years, was presented for cytogenetic analysis to confirm the clinical diagnosis of Down's syndrome and to rule out the presence of an inherited chromosome aberration. The proband was the fourth child of non-consanguineous parents. There had been one miscarriage between the first and second children. At birth both parents were 40 years old. There was no family history of either Down's or Turner's syndrome. When the proband was 7 months old, psychomotor retardation was noticed. $\mathrm{He}$ walked at the age of 2 years 6 months and developed speech at 5 years. At the age of 7 , he weighed $20.7 \mathrm{~kg}$ (25th centile) with a height of $117 \mathrm{~cm}$ (25th centile), and features of Down's syndrome were first noticed then. Clinical neurological investigation at the age of 32 was normal, but a pneumoencephalogram showed periventricular atrophy. Substitution therapy was started for primary hypothyroidism when he was 49 years old. On the Vineland Adaptive Behavior Scale his total psychological score was 4 years 8 months at the age of 53 . However, he was able to write and read. A few years later a moderate bilateral perception hearing loss was diagnosed, with a loss of $35 \mathrm{~dB}$ on the left and $53 \mathrm{~dB}$ on the right (Fletcher index). He has recently developed diabetes mellitus type II which was treated orally.

Recent investigation showed a well nourished, short statured male with a height of $156 \mathrm{~cm}(<3 \mathrm{rd}$ centile) and a weight of $64.5 \mathrm{~kg}$ (50th centile). He had a brachycephalic skull with a head circumference of $52.3 \mathrm{~cm} \quad(<3 \mathrm{rd}$ centile). His hair was sparse and there was a low posterior hairline. He had a round face with small, upward slanting palpebral fissures, a flat midface, and a normal tongue. His ears were asymmetrical and measured $7 \mathrm{~cm}$ (75th to 97 th centile) on the right and $7 \cdot 2 \mathrm{~cm}$ (75th to 97 th centile) on the left (figure). His neck was short and broad and the thorax wide with an internipple distance of $22 \mathrm{~cm}$ (97th centile). Heart auscultation was normal and he had

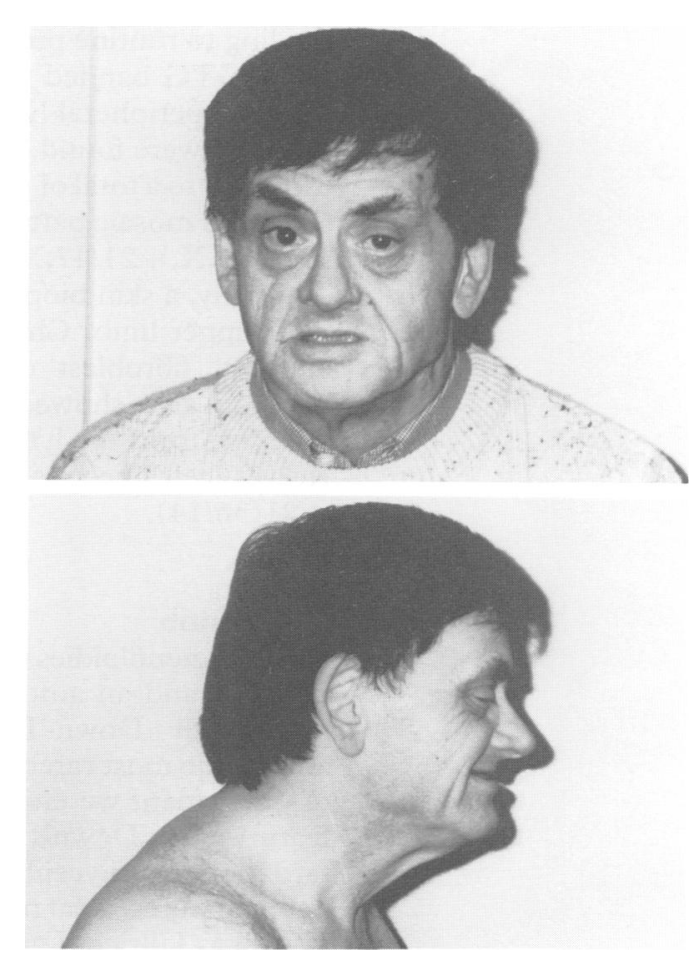

Facies and profile of the patient. 
Down-Turner syndrome: clinical features and cytogenetic findings in cultured peripheral lymphocytes of all 28 reported cases including the present case.

\begin{tabular}{|c|c|c|c|c|c|c|c|}
\hline \multirow[t]{2}{*}{ Case } & \multirow[t]{2}{*}{ Reference } & \multirow{2}{*}{$\begin{array}{l}\text { Chromosome } \\
\text { pattern }\end{array}$} & \multirow[t]{2}{*}{ Genitalia } & \multirow{2}{*}{$\begin{array}{l}\text { Clinical } \\
\text { appearance }\end{array}$} & \multirow{2}{*}{$\begin{array}{l}\text { Age of } \\
\text { patient }\end{array}$} & \multicolumn{2}{|c|}{ Parental age } \\
\hline & & & & & & $M$ & $P$ \\
\hline $\begin{array}{r}1 \\
2 \\
3 \\
4 \\
5 \\
6 \\
7 \\
8 \\
9 \\
10 \\
11 \\
12 \\
13 \\
14 \\
15 \\
16 \\
17 \\
18 \\
19 \\
20 \\
21 \\
22 \\
23 \\
24 \\
25 \\
26 \\
27 \\
28\end{array}$ & $\begin{array}{l}11 \\
2 \\
12 \\
1 \\
13 \\
14 \\
4 \\
15 \\
14 \\
16 \\
17 \\
18 \\
19 \\
20 \\
3 \\
21 \\
21 \\
22 \\
23 \\
24 \\
\text { Present report } \\
25 \\
26 \\
27 \\
28 \\
29 \\
28 \\
28\end{array}$ & $\begin{array}{l}46, \mathrm{X},+\mathrm{G} \\
45, \mathrm{X} / 46, \mathrm{X},+21 \\
45, \mathrm{X} / 47, \mathrm{XX},+\mathrm{G}^{*} \\
45, \mathrm{X} / 47, \mathrm{XX},+21^{*} \\
45, \mathrm{X} / 47, \mathrm{XX},+\mathrm{G} \\
45, \mathrm{X} / 47, \mathrm{XX},+21^{*} \\
45, \mathrm{X} / 47, \mathrm{XX},+21 \\
45, \mathrm{X} / 47, \mathrm{XY},+21^{*} \\
45, \mathrm{X} / 47, \mathrm{XY},+21 \\
46, \mathrm{X},+\mathrm{G} / 46, \mathrm{XX} \\
46, \mathrm{X},+\mathrm{G} / 47, \mathrm{XX},+\mathrm{G} \\
46, \mathrm{X},+21 / 47, \mathrm{XX},+21 \\
46, \mathrm{X},+21 / 47, \mathrm{XX},+21 \\
46, \mathrm{X},+21 / 47, \mathrm{XX},+21 \\
46, \mathrm{X},+21 / 47, \mathrm{XX},+21 \\
46, \mathrm{X},+21 / 47, \mathrm{XX},+21 \\
46, \mathrm{X},+21 / 47, \mathrm{X}, \mathrm{i} \mathrm{Xq},+21 \\
46, \mathrm{X},+21 / 47, \mathrm{XY},+21 \\
46, \mathrm{X},+21 / 47, \mathrm{XY},+21 \\
45, \mathrm{X} / 46, \mathrm{X},+\mathrm{G} / 47, \mathrm{XX},+\mathrm{G} * \\
45, \mathrm{X} / 46, \mathrm{X},+21 / 47, \mathrm{XY},+21 * \\
45, \mathrm{X} / 46, \mathrm{XX} / 47, \mathrm{XX},+\mathrm{G} \\
45, \mathrm{X} / 46, \mathrm{XY} / 47, \mathrm{XY},+21 * \\
46, \mathrm{X},+\mathrm{G} / 46, \mathrm{XX} / 47, \mathrm{XX},+\mathrm{G} \\
46, \mathrm{X},+\mathrm{G} / 46, \mathrm{XX} / 47, \mathrm{XX},+\mathrm{G} \\
45, \mathrm{X} / 46, \mathrm{X},+\mathrm{G} / 46, \mathrm{XX} / 47, \mathrm{XX},+\mathrm{G} \\
45, \mathrm{X} / 46, \mathrm{X},+\mathrm{G} / 46, \mathrm{XX} / 47, \mathrm{XX},+\mathrm{G} \\
45, \mathrm{X} / 46, \mathrm{X},+\mathrm{G} / 46, \mathrm{XX} / 47, \mathrm{XX},+\mathrm{G}\end{array}$ & $\begin{array}{l}\text { F } \\
F \\
F \\
F \\
F \\
F \\
F \\
M \\
M \\
F \\
F \\
F \\
F \\
F \\
F \\
F \\
F \\
A \\
A \\
A \\
M \\
F \\
M \\
F \\
F \\
F \\
F \\
F\end{array}$ & $\begin{array}{l}\text { DOWN } \\
\text { DOWN + turner } \\
\text { DOWN + TURNER } \\
\text { DOWN } \\
\text { DOWN } \\
\text { DOWN + turner } \\
\text { DOWN } \\
\text { DOWN } \\
\text { DOWN + turner } \\
\text { DOWN } \\
\text { DOWN + turner } \\
\text { DOWN } \\
\text { DOWN } \\
\text { DOWN } \\
\text { DOWN + TURNER } \\
\text { DOWN + turner } \\
\text { DOWN + turner } \\
\text { DOWN + turner } \\
\text { DOWN + turner } \\
\text { DOWN + TURNER } \\
\text { DOWN + TURNER } \\
\text { DOWN } \\
\text { DOWN + turner } \\
\text { DOWN + turner } \\
\text { DOWN + turner } \\
\text { down + turner } \\
\text { DOWN + turner } \\
\text { DOWN + turner }\end{array}$ & $\begin{array}{l}-\bar{y} \\
15 \mathrm{y} \\
6 \mathrm{mth} \\
\text { Newborn } \\
9 \cdot 5 \mathrm{y} \\
8 \mathrm{y} \\
5 \mathrm{y} \\
15 \mathrm{y} \\
- \\
9 \mathrm{y} \\
2 \mathrm{mth} \\
3 \mathrm{mth} \\
9 \mathrm{y} \\
5 \mathrm{y} \\
\text { Newborn } \\
\text { Newborn } \\
5 \\
5 \mathrm{mth} \\
25 \mathrm{y} \\
59 \mathrm{y} \\
7 \mathrm{y} \\
25 \mathrm{y} \\
21 \mathrm{y} \\
16 \cdot 5 \mathrm{y} \\
16 \mathrm{y} \\
17 \cdot 5 \mathrm{y} \\
13 \mathrm{y}\end{array}$ & $\begin{array}{l}\overline{29} \\
\overline{-} \\
36 \\
30 \\
24 \\
\overline{30} \\
\overline{-} \\
\overline{42} \\
26 \\
26 \\
36 \\
38 \\
18 \\
36 \\
35 \\
40 \\
27 \\
32 \\
37 \\
33 \\
27 \\
31 \\
33.5\end{array}$ & $\begin{array}{l}- \\
- \\
\bar{Z} \\
40 \\
37 \\
26 \\
\overline{37} \\
\overline{-} \\
\overline{44} \\
28 \\
\overline{28} \\
65 \\
\overline{-} \\
40 \\
\overline{40} \\
28 \\
28 \\
\overline{-} \\
29 \\
33 \\
31\end{array}$ \\
\hline
\end{tabular}

* Cases in which a fibroblast culture was also cytogenetically analysed.

Cases 3, 8, and 23: fibroblast cells = peripheral lymphocytes.

Cases 4 and 6: fibroblast cells: $47, \mathrm{XX},+21$.

Case 21 (present report): fibroblast cells: $45, \mathrm{X} / 47, \mathrm{XY},+21$.

Case 20: the cytogenetic findings of the cultured fibroblast cells are shown. The $47, \mathrm{XX},+\mathrm{G}$ cell line was not found in peripheral lymphocytes $(45, \mathrm{X} / 46, \mathrm{X},+\mathrm{G})$

$\mathrm{F}=$ female; $\mathrm{M}=$ male; $\mathrm{A}=$ ambiguous genitalia; DOWN = obvious features of Down's syndrome; down = mild features of Down's syndrome; TURNER = obvious features of Turner's syndrome; turner = mild features of Turner's syndrome.

normal sized testes. The hands were broad, with a total hand length of $25 \mathrm{~cm}$ (25th centile) bilaterally, the fifth fingers were normal, and there was no simian creases. The foot length was $21 \mathrm{~cm}$ (<3rd centile) bilaterally, there was partial syndactyly of the second and third right toe, and there was no sandal gap.

\section{CYTOGENETIC STUDIES}

Chromosome analysis was performed according to routine procedures. During analysis of 15 GTG banded metaphases derived from cultured peripheral lymphocytes, two different cell lines were found. Therefore, the study was extended to a total of 100 mitoses. This analysis showed a mosaic pattern of double aneuploidy: $45, \mathrm{X} / 46, \mathrm{X},+21 / 47, \mathrm{XY},+21(79 / 2 / 19)$. Subsequently, a skin biopsy was obtained from the right upper limb. Chromosome analysis of 50 cultured fibroblast cells after routine GTG banding also showed a mosaic pattern, but different from the lymphocytes in that the 46 , $\mathrm{X},+21$ cell line was not found: $45, \mathrm{X} / 47, \mathrm{XY}$, $+21(36 / 14)$

\section{Discussion}

Double aneuploidies involving both a sex chromosome and an autosome appear to be quite rare, with Down-Turner syndrome being among the most rarely reported. In the analysis of our patient we encountered several specific features of Down's syndrome (mental retardation, brachycephaly, upward slanting palpebral fissures, a flat midface, and short stature) as well as Ullrich-Turner syndrome (short and broad neck, low posterior hairline, wide thorax with a large internipple distance, and short stature). Mental retardation was mild as he was able to write and read and he was quite old for a pure trisomy 21 patient. There were no signs of dementia. Cytogenetic studies proved that this was because of a mosaic chromosomal pattern with trisomy 21 in only a minority of cells in two different tissues. The patient was phenotypically male although chromosome analysis showed a Y chromosome in only $19 \%$ and $28 \%$ of cultured peripheral lymphocytes and fibroblast cells, respectively.

\section{REVIEW OF PREVIOUSLY PUBLISHED CASES}

A total of 34 cases of Down-Turner syndrome have been reported so far. However, three of these cases apparently were diagnosed purely on clinical features without any cytogenetic confirmation. ${ }^{56}$ Since we reviewed only karyotyped cases, these three were not included in the table and will not be considered further.

Another three cases of Down-Turner mosaicism in which one of the $\mathrm{X}$ chromosomes showed a deletion were not included either, as they represent a different genetic entity: 47, $\mathrm{XX},+21 / 47, \mathrm{XX}, \mathrm{p}-\mathrm{q}-+21 ; 47, \mathrm{X}, \operatorname{del}(\mathrm{X})(\mathrm{p} 11)$, +21 , and $47, \mathrm{X}, \mathrm{Xq}-,+21 .^{7-9}$ Lastly, a complex case of trisomy 21 associated with $\mathrm{XO} / \mathrm{XX}$ $\mathrm{XXX}^{10}$ was also excluded.

The clinical features and chromosomal patterns of the remaining 28 patients, including our own case, are summarised in the table.

\section{Features of Down's syndrome versus Ulirich-Turner syndrome}

Eleven of the 28 patients (39\%) had the typical 
phenotype of pure Down's syndrome, including short stature, flat face, oblique palpebral fissures, depressed nasal bridge, Brushfield spots, large, protruding tongue, small ears, brachycephaly, short, broad hands and feet, short fifth fingers, a space between the first and second toes, and hypotonia at birth (cases 1 , $4,5,7,8,10,12,13,14,22$, and 23). Four patients $(14 \%)$ showed clear features of both Down's and Turner's syndromes (cases 3, 15, 20 , and 21 ), while in 12 patients $(43 \%)$ clear signs of Down's syndrome and only milder features of Ullrich-Turner syndrome were reported (cases 2, 6, 9, 11, 16, 17, 18, 19, 24, 25,27 , and 28). These less distinct features of Ullrich-Turner syndrome included: oedema of the hands and feet at birth, delayed sexual development, short stature, webbing of the neck, and ambiguous genitalia. In three of the 12 cases (cases 6,9 , and 17) oedema of the hands and feet was reported and in two patients (cases 24 and 28 ) delayed sexual development was noted. Both features are quite specific for Ullrich-Turner syndrome, whereas the other signs may be present in Down's syndrome as well. Therefore, the remaining seven patients could also be regarded as typical Down's syndrome patients based on the published data. However, since all 12 patients were earlier described as showing signs of both Down's and Ullrich-Turner syndromes we included them in this group.

In one patient only mild stigmata of both Down's and Ullrich-Turner syndromes were described (case 26).

Not a single patient has been reported with a pure Ullrich-Turner phenotype as characterised by short stature, delayed sexual development, low posterior hairline, shield chest, multiple pigmented naevi, cubitus valgus, and webbing of the neck. Thus, clinical features of Down's syndrome were always present, while a combination of Ullrich-Turner and Down's syndrome features were found in 17 patients (61\%). Apparently, the phenotypic effects of even a relatively low percentage of trisomy 21 cells are much more prominent than those of the monosomy $\mathrm{X}$ cells. However, the proportion of trisomy 21 versus monosomy $\mathrm{X}$ cells does not always correlate with the phenotype, which can probably be explained by a different mosaic distribution in various somatic tissues. ${ }^{28}$

This implies that the clinical diagnosis of Down-Turner syndrome based merely on the phenotype is very difficult to make and should be supported by cytogenetic studies in virtually all cases. The fact that clinical features of the two syndromes may coexist shows the relative autonomy of these chromosomes in morphogenesis. $^{323}$

\section{CHROMOSOMAL MOSAICISM IN DOWN-TURNER} SYNDROME

Only one patient with Down-Turner syndrome has been reported who showed a single cell type (case 1) and is, therefore, not a true mosaic. All other cases are a combination of two (cases 2-19), three (cases 20-25), or even four cell lines (cases 26-28). Our patient (case
21) had three cell lines in cultured T lymphocytes, but only two in a fibroblast culture of a skin biopsy. However, since $46, \mathrm{X},+21$ cells were found at a very low frequency in lymphocytes, we could easily have missed it if these cells had been present at a low frequency in the cells of the skin too.

\section{KARYOTYPE AND GENDER}

Only four of the six patients with a $\mathrm{Y}$ chromosome were phenotypically male while the other two showed ambiguous genitalia. One of these two patients had a bifid scrotum and a penoscrotal hypospadias with a urogenital sinus. A uterus and bilateral testes were present (case 18). The second patient also had a bifid scrotum, a perineal hypospadias, and a urogenital sinus. He had bilateral small testes but no internal female organs (case 19). Of the 22 patients without a Y chromosome, 21 were phenotypically female. The remaining patient showed ambiguous genitalia, presenting with "hermaphroditic" external genitalia, a rudimentary uterus, and no ovaries or testes (case 20). This is in accordance with the observation that patients with Ullrich-Turner mosaicism are known to show a wide spectrum of different phenotypic expression ranging from normal females, females with mixed gonadal dysgenesis and male pseudohermaphroditism to almost normal males. ${ }^{3031}$

Our patient was phenotypically male although chromosome analysis showed a $\mathrm{Y}$ chromosome in only a minority of his cells. In general, the phenotypic appearance of the genitalia is probably a result of the chromosomal mosaicism as present in the various tissues, since two patients who carried a Y chromosome and one with $\mathrm{X}$ chromosomal mosaicism had ambiguous external genitalia.

LITTLE MOSAICISM OF Y CHROMOSOME IN DOWN-TURNER SYNDROME

From the 28 reported patients, only six (21\%) had a Y chromosome, which is far less than expected. Since all described cases with DownTurner syndrome showed clinical signs of Down's syndrome, it seems unlikely that (male) patients with a $\mathrm{Y}$ chromosome in a certain proportion of their cells would not be traced. Assuming that the sex chromosomal mosaicism in the reviewed cases is probably caused by anaphase lagging, in XX zygotes loss of either $\mathrm{X}$ chromosome would be viable, leading to a mosaic situation. However, in an XY zygote lagging of the $\mathrm{Y}$ chromosome only would lead to a mosaic fetus $(45, \mathrm{X} / 46, \mathrm{XY})$, because lagging of the $\mathrm{X}$ results in a non-viable $45, \mathrm{Y}$ cell. This effect considerably reduces the number of sex chromosome mosaics carrying a $\mathrm{Y}$ chromosome. Whether there are any other selection mechanisms reducing the number of $\mathrm{Y}$ chromosome mosaics in Down-Turner syndrome, for instance during embryogenesis, is unknown at present.

We would like to thank Bert Janssen and Yvonne Tjon Hing Sang for excellent technical assistance. 
Cohen MM, Davidson RG. Double aneuploidy $(47, \mathrm{XX}$, $21+/ 45, \mathrm{X})$ arising through simultaneous double non$21+/ 45, X)$ arising through simultane
disjunction. $\mathcal{f}$ Med Genet $1972 ; 9: 242-4$.

2 Townes PL, White MR, Stiffler SJ, Kong-oo Goh. Double aneuploidy. Turner-Down syndrome. Am $f$ Dis Child 1975;129:1062-5.

3 Gatrad AR. Congenital dislocation of the knees in a child with Down-mosaic Turner syndrome. 7 Med Genet 1981; 18:148-51.

4 Jansen S, Kruger AJ, Liebenberg G. Turner/Down mosaicism. A case report. $S$ Afr Med f 1991;79:731-2.

5 Villaverde MM. Turner's syndrome accompanied by mongolism: multiple degenerative state. $\mathcal{F}$ Clin Endocrinol 1951; golism:

6 Hanhardt E. 800 Fälle von Mongoloidismus (Down's syndrome) in konstitutioneller Betrachtung. Arch fulius-Stiftung 1960;35:1-132. Quoted in Villaverde $M M$, Da Silva
JA. Turner-mongolism polysyndrome. Review of the first eight known cases. $\mathcal{F} A M A$ 1975;234:844-7.

Mikelsaar AVN, Blumina MG, Kuznetzova LI, Mikelsaar RV-A, Lurie IV. A double chromosome aberration 47, XX, $21+/ 47, \mathrm{XX}, \mathrm{p}-\mathrm{q}-, 21+$ in a girl with symptoms of Down's and Turner's syndromes. Genetika SSSR 1971;7:156-61.

8 Martsolf JT, Ray M, Bauder F, Boychuk R, Armstrong JD. Down and Turner syndromes in a female infant with 47, $\mathrm{X}, \operatorname{del}(\mathrm{X})(\mathrm{p} 11),+21$. Hum Genet 1977;39:103-8.

9 Luthardt FW, Palmer CG. X chromosome long arm deletion in a patient with Down's syndrome. $\mathcal{F}$ Med Genet 1971;8: in a patient

10 Zergollern L, Hoefnagel D. X-chromosome mosaicism with trisomy-21. Lancet 1964;i:1108-9.

11 Baguena Candela R, Forteza Bover G, Ortiz Hernandez $\mathrm{MD}$, Comin Ferrer J. Un caso con estigmas del síndrome de Bonnevie-Ullrich y de mongolismo y cariotipo 45, XOtrisomia G. Med Española 1966;55:454-61. Quoted in Hustinx TJW, Ter Haar BGA, Scheres JMJC, Rutten FJ. Autosomal/heterosomal mixoploidy: a report on two patients, a female with a $45, \mathrm{X} / 47, \mathrm{XX},+21$ and a male with a $45, \mathrm{X} / 47, \mathrm{XY}, 21$ chromosome constitution. Ann Genet (Paris) 1974;17:225-34.

12 Taylor AI. Further observations of cell selection in vivo in normal/G trisomic mosaics. Nature 1970;227:163-4.

13 Barakat BY, Der Kaloustian VM. Combined autosomalsex chromosomal mosaicism in a newborn female with mongolism. 4th International Conference on Birth Defects, Vienna. Amsterdam: Excerpta Medica, 1973;73.

14 Hustinx TWJ, Ter Haar BGA, Scheres JMJC, Rutten FJ. Autosomal/heterosomal mixoploidy: a report on two patients, a female with a $45, \mathrm{X} / 47, \mathrm{XX},+21$ and a male with a $45, \mathrm{X} / 47, \mathrm{XY},+21$ chromosome constitution. Ann Genet (Paris) 1974;17:225-34.

15 Prieur M, Dutrillaux B, Carpentier S, et al. Mosaïque 45, $\mathrm{X} / 47, \mathrm{XY},+21$. Ann Genet (Paris) 1972;15:195-6.

16 Baguena Candela R, Forteza Bover G, Amat Aguirre E. Un nuevo tipo de aberración cromosómica: el mosaico normal/ trisomía G-monosomía XO. Med Española 1965;54:256-
62. Quoted in Hustinx TWJ, Ter Haar BGA, Scheres JMJC, Rutten FJ. Autosomal/heterosomal mixoploidy: a report on two patients, a female with a $45, \mathrm{X} / 47, \mathrm{XX}$ +21 and a male with a $45, \mathrm{X} / 47, \mathrm{XY},+21$ chromosom constitution. Ann Genet (Paris) 1974,17:225-34.

17 Medenis R, Forbes A, Rosenthal IM. Mosaicism associated with mongolism. Read before the 32nd Annual Meeting of the Society for Pediatric Research, Atlanta City, 1962, 72A. Quoted in Root AW, Bongiovanni AM, Breibart S Mellman WJ. Double aneuploidy: trisomy 21 and $\mathrm{XO}$ XX sex chromosome mosaicism. F Pediatr 1964;65:937-9.

18 Root AW, Bongiovanni AM, Breibart S, Mellman WJ Double aneuploidy: trisomy 21 and $\mathrm{XO} / \mathrm{XX}$ sex chromosome mosaicism. $\mathcal{f}$ Pediatr 1964;65:937-9.

19 van Wijck JAM, Blankenborg GJ, Stolte LAM. XO/XX mosaicism and mongolism in the same person. Lancet 1964;i: 171

20 Pfeiffer RA, Scharfenberg W, Büchner T, Stolecke H. Ringchromosomen und zentrische Fragmente bei TurnerSyndrom. Geburtsh und Frauenheilk 1968;28:12. Quoted in Mikelsaar AVN, Blumina MG, Kuznetzova LI, Mikelsaar RVA, Lurie IV. A double chromosome aberration 47, XX, $21+/ 47, \mathrm{XXp}-\mathrm{q}-, 21+$ in a girl with symptoms of Down's $21+/ 47, \mathrm{XXp}-\mathrm{q}-, 21+$ in a girl with symptoms of 1 .

21 MacFaul R, Turner T, Mason MK. Down's/Turner's mosaicism. Double aneuploidy as a rare cause of missed prenatal diagnosis of chromosomal abnormality. Arch Dis Child 1981;56:962-3.

22 Santos Mello R, Souza OA, Santos Mello EMKS, Pimente EC. Patient with Down's syndrome and male pseudohermaphroditism with a $47, \mathrm{XY},+21 / 46, \mathrm{X},+21$ karyotype. Clin Genet 1974;5:259-62.

23 Yeung CY, Yang L. Down's syndrome with XO/XY mosaicism. Acta Paediatr Scand 1976;65:391-5.

24 Villaverde MM, Da Silva JA. Turner-mongolism polysyndrome. Review of the first eight known cases. $f A M A$ 1975;234:844-7.

25 Grosse KP, Hopfengärtner F, Schwanitz G. Doppelte Aneuploidie: 46,XX/45,XO/47, XX,G+. Kasuistische Mitteilung. Humangenetik 1971;13:333-7.

26 Edgren J, de la Chapelle A, Kääriäinen R. Cytogenetic study of seventy-three patients with Down's syndrome. $\mathcal{f}$ Ment of seventy-three patients
Defic Res 1966;10:47-62.

27 van Gelderen HH, Gaillard JLJ, Schaberg A. Trisomy G/ normal mosaics in non-mongoloid mentally deficient chilnormal mosaics in non-mongoloid mentally

28 Singh DN, Osborne RA, Hennigar GR, Barnett CD. Mosaic double aneuploidy of $\mathrm{X}$ and $\mathrm{G}$ chromosomes. Am $\mathcal{f}$ Ment double aneuploidy of
Defic $1975 ; 79: 644-7$.

29 Feiertag-Koppen CCM, Anders GJPA, Stronk MG, Boevé HJ. Mosaicism of X and G chromosomes. Lancet 1966;i: 1271

30 Davidoff F, Federman DD. Mixed gonadal dysgenesis. Pediatrics 1973;52:725-42.

31 Knudtzon J, Aarskog D. 45,X/46,XY mosaicism. A clinical review and report of ten cases. Eur $\mathcal{F}$ Pediatr 1987;146: 266-71. 